ACTA AGROBOTANICA

Vol. 61 (2): 57-64

2008

\title{
ANNUAL POLLEN SUMS OF ALNUS IN LUBLIN AND ROZTOCZE IN THE YEARS 2001-2007 AGAINST SELECTED METEOROLOGICAL PARAMETERS
}

\author{
Boguslaw Michal Kaszewski ${ }^{1}$, Irena Agnieszka Pidek ${ }^{1}$, \\ Krystyna Piotrowska ${ }^{2}$, Elżbieta Weryszko-Chmielewska ${ }^{2}$
}

\author{
${ }^{1}$ Institute of Earth Sciences, Maria Curie-Sklodowska University, al. Krasnicka 2 c/d, 20-718 Lublin, Poland \\ e-mail: i.pidek@poczta.umcs.lublin.pl \\ ${ }^{2}$ Department of Botany, University of Life Sciences in Lublin, Akademicka 15, 20-950 Lublin, Poland
}

Received: 10.10 .2008

$\mathrm{Su} \mathrm{m} \mathrm{m}$ a r y

Alder (Alnus Mill.), as an anemophilous species, produces large quantities of easily dispersed pollen. Annual pollen sums recorded in south-eastern Poland (by the volumetric method - Lanzoni trap) and in the area of the village of Guciów in the Central Roztocze region (pollen deposition in Tauber traps) were compared. The height at which the respective trap sites were located as well as local and regional vegetation and the distance from the nearest alder communities differ in both cases, likewise, the climate of these two regions differ. The analysed pollen data series cover the years 1998-2007 in Roztocze and 2001-2007 in Lublin. Large differences have been noted in Alnus pollen deposition values between particular years. Among them, there were observed years of very high annual sums $(2001,2003,2006)$, as well as years of very low pollen deposition values in both regions $(2002,2005,2007)$. In the period in question, the mean value of annual Alnus pollen count for Lublin was 5372 alder pollen grains in $\mathrm{m}^{3}$ of air, and in Roztocze 1647 grains per $\mathrm{cm}^{2}$ of area. During the seven-year period of monitoring (2001-2007), very similar trends were noted with respect to airborne alder pollen concentrations at both trap sites. Pollen data have been analysed against meteorological factors affecting alder pollen production and deposition. These are total precipitation and mean monthly air temperature in June, July and August in the year preceding pollen emission and the same weather elements in January and February in the year of pollen emission. In Roztocze a statistically significant negative correlation has been found between Alnus pollen annual sums and total precipitation in August in the year preceding alder pollen emission and in February in the year of pollen emission. In both regions, the Spearman's correlation coefficient does not show any statistically significant values when comparing annual $\mathrm{Al}$ nus pollen sums with mean monthly temperatures of both January and February and summer months in the year preceding alder pollen emission.

Key words: pollen monitoring, Alnus pollen, modern pollen deposition, Lanzoni trap, Tauber traps

\section{INTRODUCTION}

Alders (Alnus Mill.), belonging to the family Betulaceae, produce large quantities of pollen causing allergic reactions. In addition, alder together with hazel are an important source of fresh pollen for bees in early spring, since there is a shortage of other flowering plants. As it has been calculated, the number of pollen grains produced by one inflorescence of alder is ca. 19.5 million, which is 2.2 times higher than those produced by the hazel inflorescence (P i o t r o w s k a, 2008). Due to its abundant pollen production and allergenic properties, alder is in the range of interest not only of botanists and aerobiologists, but also allergologists.

Three alder species of the genus Alnus Mill. occur in Poland, among which black alder (Alnus glutinosa /L./ Gaertn.) is most commonly found ( $\mathrm{Z} \mathrm{a} \mathrm{j} \mathrm{ąc}$ and $\mathrm{Zajac} c$, 2001). Alnus pollen appears in the air very early, often already in the first decade of February (Kasprzyk et al. 2004; S zczepanek, 2006; Smith et al. 2007; Weryszko-Chmielewska and Piotrowska, 2004; 2006). Due to cross reactions to alder and birch pollen, researchers undertake not only analyses of alder pollen concentrations, but also of pollen season patterns and related meteorological factors (Gioulekas et al. 2004; Kasprzyk et al. 2004; Rodrigues-Rajo et al. 2006; S mith et al. 2007).

Since 1998 we have had pollen fall data series available from the Central Roztocze region - (the area of Guciów) collected based on modified Tauber traps under the Pollen Monitoring Programme (PMP). This project is designed to trace the dispersal and deposition of pollen of different taxa under as natural conditions as possible (http://pmp.oulu.fi). The Wieprz 
river valley in the area of Guciów, with alder carrs (Ribeso nigri-Alnetum) and initial forms of ash-alder riparian forests (Fraxino-Alnetum) running along the river channel (Grąziel et al. 2006; Izdebski et al. 1992), is the main source of Alnus pollen ( $\mathrm{Pidek}$, 2007).

Monitoring studies carried out by the volumetric method using the Lanzoni trap have been conducted in Lublin since 2001. In spite of essential differences in the methodology of pollen capture and measurements of its annual sums, it has been demonstrated that results of monitoring of annual pollen influx using the Tauber trap and the volumetric method are well correlated (L e vetin et al. 2000; Ranta et al. 2007).

The present study is designed to analyse tenyear (1998-2007) pollen data series from the area of Guciów and seven-year (2001-2007) series of monitoring measurements of alder pollen concentrations in Lublin against selected weather elements. Previous studies have demonstrated that alder flowers set already in the second half of June in the year preceding flowering, and at the end of July meioses already take place in pollen mother cells (Krawiarz and Chałupka, 1980). In addition, pollen release is affected by weather 10 days before its onset (S u s zka, 1980). Warm and dry weather promotes pollen release. Hence, it seems that analysis of air temperature in June, July and August of the year preceding flowering as well as of temperature and precipitation levels in January and February of the year of pollen emission may shed light on the problem of occurrence of years of abundant and poor Alnus pollen production. An analysis of the pattern of occurrence of such years (Pidek et al. 2008) indicates that the climatic signal may be of decisive importance for the occurrence of an "abundant" or "average" year after a "poor" one.

\section{MATERIALS AND METHODS}

\section{Pollen monitoring}

In Lublin measurements of pollen concentration in the air were made by the volumetric method using a Lanzoni VPPS 2000 pollen trap which was sited at a height of 18 metres. The trap site was located in the Śródmieście district (city centre) $\left(\varphi=51^{\circ} 14^{\prime} 37^{\prime \prime} N\right.$ and $\left.\lambda=22^{\circ} 32^{\prime} 25^{\prime \prime} \mathrm{E}\right)$ at a large distance from alder communities.

The total annual concentration of Alnus pollen grains was calculated by adding up diurnal pollen concentrations in $1 \mathrm{~m}^{3}$ of atmospheric air on particular days of the year.

In Roztocze measurements of annual Alnus pollen deposition, made using nine Tauber traps (Tau ber, 1974; Hicks and Hyvärinen, 1986), have been carried out since 1998 under the Pollen Moni- toring Programme (PMP). The annual pollen catch is subjected to laboratory treatment using Lycopodium marker tablets (S t o c k marr, 1971), and subsequently microscopic analysis (Hicks et al. 1996). Based on the known number of added Lycopodium clavatum spores in relation to the number of spores of this species encountered in microscopic analysis, the number of Alnus pollen grains deposited annually on $\mathrm{cm}^{2}$ can be calculated. A detailed description of the methodology, published by Hicks and co-authors (1996; 1999), is available on the website http:// pmp.oulu.fi.

In Roztocze plastic containers converted into Tauber traps were used. A $5 \mathrm{~cm}$ diameter opening was covered with large wire mesh (vide Pidek, 2004). After adding five Lycopodium tablets, the contents of the trap were filtered and subjected to standard acetolysis treatment. During the microscopic analysis, the counting was continued until a minimum of 500 pollen grains of trees and shrubs (AP) and a minimum of 100 Lycopodium spores were obtained.

In the case of the PMP method, the mean sum of pollen grains, deposited on one $\mathrm{cm}^{2}$ of area, obtained based on the results from four trap sites of supralocal importance located in open landscape in the area of Guciów or in large openings with a diameter of 80-100 $\mathrm{m}$ (sites no. 4, 6, 7 and 8 ), was accepted as the annual pollen sum in a particular year. The results from the other sites, located in small forest openings, were not taken into account, since local vegetation is mainly reflected in them. Geographic coordinates of the monitoring sites in the area of Guciów included in the present paper are presented in Table 1.

Table 1

Geographic coordinates of the trap sites in Roztocze.

\begin{tabular}{|c|c|c|}
\hline Trap no & $\varphi$ & $\lambda$ \\
\hline 4 & $50^{0} 35^{\prime} 04,1 " \mathrm{~N}$ & $23^{\circ} 03^{\prime} 27,6$ " E \\
\hline 6 & $50^{0} 34^{\prime} 55,7{ }^{\prime \prime} \mathrm{N}$ & $23^{0} 04^{\prime} 00,1^{\prime \prime} \mathrm{E}$ \\
\hline 7 & $50^{0} 34^{\prime} 57,4^{\prime \prime} \mathrm{N}$ & $23^{\circ} 04^{\prime} 24,9^{\prime \prime} \mathrm{E}$ \\
\hline 8 & $50^{0} 34^{\prime} 21,2 " \mathrm{~N}$ & $23^{\circ} 03^{\prime} 14,1^{\prime \prime} \mathrm{E}$ \\
\hline
\end{tabular}

In order to compare annual Alnus pollen deposition and its airborne content, with respect to the data obtained using the two methods (the PMP method in Roztocze and the volumetric method in Lublin), the percentage pollen index (PI) was calculated for 20012007 measurement series in accordance with the following formula:

$\mathrm{PI}=($ annual pollen sum in a particular year $/$ annual pollen sum in the 7 -year period) $x 100 \%$

In Table 2 the annual Alnus pollen sum is given, which is the averaged value from 4 selected traps (no. 4, 6, 7 and 8) for each year in the analysed period 
2001-2007. Due to the destruction of trap no. 8 during the 2001 growing season and trap no. 4 in 2005 , the sum for these two years is calculated based on three, not four values.

Table 2 contains a summary of results of the calculation of the annual alder pollen sum from Lublin and Roztocze as well as the percentage share of the alder pollen sum from a given year in the total sum for the years 2001-2007. The sum values higher than the mean for the years $2001-2007$ by at least $30 \%$ are taken to be high values and they are marked in red in Table 2, whereas the values lower by at least $30 \%$ are marked as low values (in green).

In addition, results are compared between the annual sums for the years 1998-2000, which were obtained for Alnus using the gravimetric method in Lublin (Durham sampler) and in Roztocze using the PMP method (Tab. 3).

\section{Alder in the trap site areas}

Alder in Lublin grows in the valleys of the Bystrzyca and Czechówka rivers, in habitats periodically inundated by surface waters. Its nearest stands were located from the pollen trap at a distance of about $2-3 \mathrm{~km}$.

Alder in the area of Guciów in Roztocze:

Alder communities in Roztocze are primarily associated with peat soils in the Wieprz river valley and with drainless terrain depressions. In the area of the village of Guciów, on the Wieprz river floodplain terrace, alder forms patches of Ribeso nigri-Alnetum and Fraxino-Alnetum associations. They cover an area of about 4 ha (Gradziel et al. 2006) in the village of Guciów itself (the nomenclature of the associations follows Matuszkiewicz, 2001).

\section{Meteorological data}

The Spearman's rank correlation coefficient $\left(\mathrm{r}_{\mathrm{s})}\right)$ was used to evaluate the effect of air temperature and precipitation on the abundance of Alnus pollen,

$$
r_{S}=1-\frac{6 \sum D^{2}}{N\left(N^{2}-1\right)}
$$

where: $\Sigma D^{2}$ - the sum of squares of differences between the ranks, $N$ - the number of pairs of measurements.

This coefficient is used in the so-called small samples where the number of pairs of measurements (i.e. $\mathrm{N}$ ) is less than 30 , and there is no assumption of the normality of distribution and linearity between two variables (Ł o m n i c ki, 1995).

Coefficients of correlation were calculated between the alder pollen sum in a particular year and mean air temperature in June, July and August in the year preceding pollen emission as well as in January and February of the year of pollen emission, and also between the pollen sum in a particular year and total precipitation in June, July and August in the year preceding pollen emission as well as in January and February of the year of pollen emission in Lublin and in Zwierzyniec in Roztocze.

Data on air temperature and precipitation came from the Meteorological Observatory of the Meteorology and Climatology Department, the Maria CurieSklodowska University in Lublin (Poland), located in the city centre in a tree-covered city centre square $\left(\varphi=51^{\circ} 15^{\prime} \mathrm{N} ; \lambda=22^{\circ} 34^{\prime} \mathrm{E} ; \mathrm{H}=195.3 \mathrm{~m}\right.$ a.s.l. $)$, at a distance of about $1.5 \mathrm{~km}$ from the pollen trap site in Lublin, and from the Meteorological Station of the Roztocze National Park in Zwierzyniec $\left(\varphi=50^{\circ} 37^{\prime} \mathrm{N}\right.$; $\lambda=22^{\circ} 58^{\prime} \mathrm{E} ; \mathrm{H}=230 \mathrm{~m}$ a.s.1.), located at a distance of about $7 \mathrm{~km}$ from the trap sites in question placed in the area of Guciów. In the case of Lublin, meteorological data for the years 2001-2007 were used, and in the case of Zwierzyniec data for the years 1998-2007.

\section{RESULTS}

\section{Pollen data}

The Alnus pollen deposition values differed much in particular years and depending on the site of the measurements (Tab. 2). Annual alder pollen sums in Lublin were from 7979 (in 2006) to 2545 grains $\times \mathrm{m}^{3}$ of air (in 2002). In Roztocze annual pollen sums ranged between 2950 (in 2006) and 568 grains $\times \mathrm{cm}^{-2}$ of area (in 2005). In the period considered, the mean value of annual alder pollen concentrations in Lublin (2001-2007) was 5372 grains.

Based on the results from the four sites in question obtained over the seven-year period of monitoring, the mean rate of annual alder pollen deposition for Roztocze was 1674 pollen grains $\times \mathrm{cm}^{-2}$.

Figure 1 shows that the differences in the values of annual sums between the regions were lower than the differences between particular years. Years of very abundant pollen deposition were observed (2003 and 2006), in which the annual sum exceeded by at least $30 \%$ the mean alder pollen catch from the seven-year period. In this respect, the next is the year 2001 in which annual sums exceed significantly the seven-year mean and the PI is $16.5 \%$ for Lublin, and for Roztocze $24.6 \%$ (Tab. 2). Low values of annual Alnus pollen sums were recorded in 2002 and 2007 (PI 6.8-10.8\% at both trap sites). In the years 2004 and 2005, the trend in Roztocze and in Lublin was slightly different. In Roztocze distinctly low alder pollen depositions were noted (PI 4.9-9.1\%), whereas in Lublin these years should be considered to be "abundant" (2004) or "average" (2005) in terms of annual alder pollen sums obtained (Fig. 1). 
Table 2

Annual alder pollen sums from Lublin and Roztocze and the pollen index. The sum values higher than the mean for the years 2001-2007 by at least 30\% are marked in red (high values). The values lower by at least $30 \%$ (low values) are marked in green. Black colour means values close to the seven-year mean.

\begin{tabular}{|c|c|c|c|c|}
\hline Year & $\begin{array}{c}\text { LUBLIN } \\
\text { Annual } \\
\text { pollen sum }\end{array}$ & $\begin{array}{c}\text { LUBLIN } \\
\% \text { pollen index }\end{array}$ & $\begin{array}{c}\text { ROZTOCZE } \\
\text { Annual } \\
\text { pollen sum }\end{array}$ & $\begin{array}{l}\text { ROZTOCZE } \\
\text { \% pollen index }\end{array}$ \\
\hline 2001 & 6216 & 16.5 & 2836 & 24.6 \\
\hline 2002 & 2545 & 6.8 & 1247 & 10.8 \\
\hline 2003 & 7095 & 18.9 & 2015 & 17.5 \\
\hline 2004 & 5761 & 15.3 & 1051 & 9.1 \\
\hline 2005 & 4467 & 11.9 & 568 & 4.9 \\
\hline 2006 & 7979 & 21.2 & 2950 & 25.6 \\
\hline 2007 & 3538 & 9.4 & 861 & 7.5 \\
\hline average & 5372 & & 1647 & \\
\hline sum & 37601 & $100 \%$ & 11528 & $100 \%$ \\
\hline
\end{tabular}

Table 3

Annual Alnus pollen sums in Lublin (Durham gravimetric sampler) and in Roztocze (PMP method) in the years 1998-2000.

\begin{tabular}{ccc}
\hline Year & $\begin{array}{c}\text { Roztocze } \\
\text { Annual } \text { Alnus } \text { pollen sum per } \mathrm{cm}^{2}\end{array}$ & $\begin{array}{c}\text { Lublin } \\
\text { Annual } \text { Alnus } \text { pollen sum per } \mathrm{cm}^{2}\end{array}$ \\
\hline 1998 & 5374 & 1329 \\
1999 & 661 & 390 \\
2000 & 225 & 148 \\
average & $\mathbf{2 0 8 6}$ & $\mathbf{6 2 2}$ \\
\hline
\end{tabular}

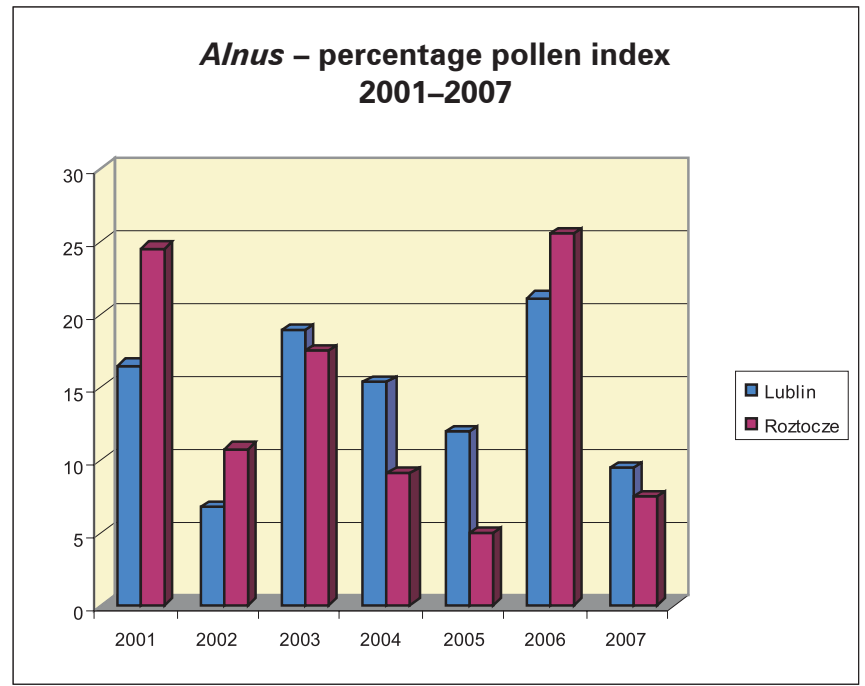

Fig. 1. The percentage pollen index (PI) for alder in the years 2001-2007 in Lublin and in Roztocze. 
The application of the results from the sevenyear period of 2001-2007 to the data obtained from the first three years of pollen monitoring conducted in Lublin by the gravimetric method (Durham sampler) allows the observation series to be extended both in Lublin and in Roztocze by including additional three years, i.e. 1998-2000 (Tab. 3).

Measurements made using the Durham gravimetric sampler in Lublin exhibited the same trend as was noted in the period 1998-2000 in Roztocze with respect to the occurrence of "abundant" and "poor" years. At both trap sites, high values for alder pollen were recorded in 1998, whereas in the next two years low values were noted.

\section{Meteorological data}

The study areas in question, compared to Poland as a whole, are distinguished in terms of inflow of solar radiation and relative insolation as well as the length of snow cover (K a s z e w s k i, 2008).
Mean annual air temperature in Lublin calculated for the years $1951-2007$ is $8.2^{\circ} \mathrm{C}$. The coldest month is January with mean temperature of $-2.8^{\circ} \mathrm{C}$, and the warmest month is July with mean temperature of $18.9^{\circ} \mathrm{C}$.

Mean annual total precipitation in Lublin for the same period is $546 \mathrm{~mm}$. On an annualised basis, the lowest annual totals are observed in January $-27 \mathrm{~mm}$, and the highest in July $-80 \mathrm{~mm}$.

Compared to Lublin, the climate of Zwierzyniec in Roztocze is characterised by lower air temperature (by about $1-2^{\circ} \mathrm{C}$ ) and higher precipitation totals (by about $100 \mathrm{~mm}$ ).

In a comparable period (2001-2007), mean annual air temperature in Lublin was $9.1^{\circ} \mathrm{C}$ and it was $1.5^{\circ} \mathrm{C}$ higher than in Zwierzyniec (Tab. 4). Mean temperature of the warmest month (July) was $20.9^{\circ} \mathrm{C}$ and it was $1.4^{\circ} \mathrm{C}$ higher than in Zwierzyniec, and of the coldest month (January) $-1.9^{\circ} \mathrm{C}$, i.e. $1^{\circ} \mathrm{C}$ higher than in Zwierzyniec.

Table 4

Mean monthly air temperatures $\left({ }^{\circ} \mathrm{C}\right)-\mathbf{a}$ and precipitation totals (in $\mathrm{mm}$ ) - b, in Lublin and Zwierzyniec in the years 2001-2007.

\begin{tabular}{|c|c|c|c|c|c|c|c|c|c|c|c|c|c|c|}
\hline & & I & II & III & IV & V & VI & VII & VIII & IX & $\mathrm{X}$ & XI & XII & year \\
\hline \multirow{2}{*}{$\mathrm{a}$} & Lublin & -1.9 & -1.4 & 3.0 & 9.3 & 15.3 & 17.5 & 20.9 & 19.4 & 14.3 & 9.2 & 3.9 & -0.8 & 9.1 \\
\hline & Zwierzyniec & -2.9 & -2.5 & 1.6 & 7.5 & 13.9 & 16.5 & 19.5 & 17.5 & 11.4 & 7.9 & 3.2 & -1.9 & 7.6 \\
\hline \multirow{2}{*}{$\mathrm{b}$} & Lublin & 31 & 32 & 34 & 37 & 55 & 56 & 96 & 66 & 57 & 29 & 29 & 21 & 542 \\
\hline & Zwierzyniec & 58 & 43 & 46 & 45 & 69 & 69 & 103 & 67 & 50 & 41 & 52 & 36 & 680 \\
\hline
\end{tabular}

Mean annual total precipitation in Lublin was nearly $140 \mathrm{~mm}$ lower than in Zwierzyniec. Only in September monthly total precipitation in Lublin was higher than in Zwierzyniec (Tab. 4).

The analysis of the Spearman's rank correlation coefficient $\left(\mathrm{r}_{\mathrm{s}}\right.$ ) between the annual Alnus pollen sum and mean temperature and precipitation in Lublin in June, July and August in the year preceding pollen emission shows that the obtained values are not statistically significant. In the case of June, these are positive values, and in the case of July and August - negative (Tab. 5).
Much higher absolute values of the correlation coefficient (although also statistically insignificant) were obtained in the case of the correlation between the annual alder pollen sum in Lublin and mean temperature and total precipitation in the months in which pollen emission takes place or in the months directly preceding pollen emission, i.e. January and February (Tab. 5).

In the case of Zwierzyniec (Roztocze), the data for the selected months (VI, VII, VIII) of the year preceding pollen emission covered 9 years. In the case of the analysis of the correlation between the annual

Table 5

Values of the Spearman's rank correlation coefficient (rs) for the annual Alnus pollen sum and mean monthly air temperature (a) and precipitation totals (b) in Lublin (explanations in the text).

\begin{tabular}{cccccc}
\hline & \multicolumn{2}{c}{ Months of the year preceding pollen emission } & \multicolumn{2}{c}{ Months in the year of pollen emission } \\
\hline & VI & VII & VIII & I & II \\
a & 0.24 & -0.21 & -0.21 & -0.43 & -0.68 \\
b & 0.07 & -0.29 & -0.29 & -0.61 & -0.64 \\
\hline
\end{tabular}


Alnus pollen sum and mean temperature and precipitation in January and February in the year of pollen emission, 10-year data series were used.

As shown in Tab. 6, the correlation coefficient values were statistically significant at the level of 0.05 for precipitation in August in the year preceding pollen emission and in February of the year of pollen emission. In both cases, a negative correlation was obtained.

Table 6

Values of the Spearman's rank correlation coefficient (rs) for the annual Alnus pollen sum and mean monthly air temperature (a) and precipitation totals (b) in Zwierzyniec (Roztocze) (explanations in the text). Statistically significant correlation values are marked in green.

\begin{tabular}{cccccc}
\hline & \multicolumn{2}{c}{ Months of the year preceding pollen emission } & \multicolumn{2}{c}{ Months in the year of pollen emission } \\
\hline & VI & VII & VIII & I & II \\
a & -0.52 & -0.07 & 0.35 & -0.10 & -0.07 \\
b & 0.37 & 0.17 & $-0.68^{*}$ & -0.26 & $-0.63^{*}$ \\
\hline
\end{tabular}

${ }^{\star}$ Correlation statistically significant $(\mathrm{p}<0.05)$.

\section{DISCUSSION}

Significant differences in the values of annual Alnus pollen sums in particular years result from differentiated pollen production which is determined by many factors. Several-year-long counts of plant pollen deposition in Kraków made by the gravimetric method (1993-1997) show that annual sums for Alnus pollen ranged between 359 and 1749 ( $\mathrm{S} \mathrm{z} \mathrm{c} \mathrm{z} \mathrm{e} \mathrm{p} \mathrm{a} \mathrm{n} \mathrm{e} \mathrm{k,}$ 2006). In spite of the fact that, as a rule, abundant years were followed by years of low or average alder pollen production, in the seven-year period (2001-2007) analysed by us there was no clear biennial pattern of abundant alder pollen deposition. Its occurrence has been considered by, among others, Spanish aerobiologists (R odrigue z-R a jo et al. 2004). Emberlin and Smith (2007) have also found a slight indication of a biennial pattern occurring for Alnus in Worcester (UK) in the years 1996-2005. In Warsaw an indication of a biennial pattern was also observed in the sevenyear period 2001-2007, in which the years 2006 and 2007 were an exception (Weryszko-Chmielewska and Rapiejko, 2007). But in Lublin and in Roztocze, the years 2004 and 2005 do not fit in such pattern. The year of very abundant Alnus pollen deposition (2006) was preceded by two "poor" years. Aira et al. (1998) also draw their attention to such phenomenon. On the other hand, a summary of levels of annual Betula and Alnus pollen sums recorded in Poland's cities distant from each other (Kraków, Poznań, Lublin, Szczecin, Rzeszów, Sosnowiec) in the years 20012005 , prepared based on a collective work edited by E. Werys zko-Ch mi elew ska (2006), shows high consistency in terms of the occurrence of "abundant" and "poor" years existing on a wide regional scale (P i $\mathrm{d}$ e k et al. 2008). This fact may suggest an essential role of the climatic factor in alder pollen production and release.

In the present paper, the analysis of weather elements potentially affecting alder pollen production and dispersion has shown that in the case of Roztocze, where we have 10-year pollen data series, precipitation levels in August of the year preceding pollen emission and in February in the year of pollen emission are of essential significance. This latter conclusion is consistent with observations of Dąbrowska (2008). She has demonstrated that in the years 2001-2006 the level of alder pollen production in Lublin increased together with an increase in relative humidity and rainfall in the pollen season. The increase in relative air humidity also prolonged the alder pollen season.

\section{Acknowledgments}

This study was partially financed by research funds for the years 2007-2010 under a research project N30409232/3590 of the Ministry of Science and Higher Education in Poland.

\section{REFERENCES}

A ir a M. J., Jato M. V., Iglesias M. I., 1998. Alnus and Betula pollen content in the atmosphere of Santiago de Compostella, North-West Spain (1993-1995). Aerobiologia, 14; 135-140.

Dąbrowska A. 2008. The influence of weather conditions on the course of pollen season of alder (Alnus spp.), hazel (Corylus spp.) and birch (Betula spp.) in Lublin (2001-2006). Acta Agrobot. 61 (1): 53-57. 
Gioulekas D., Balafoutis Ch., Damialis A., Papakosta D., Giolekas G., Patakas D. 2004. Fifteen years' record of airborne allergenic pollen and meteorological parameters in Thessaloniki, Greece. J. Biometeorol, 48: 128-136.

Grądziel T., Janicki G., Furtak T., Pidek I. A., Rodzik J., 2006. Ocena stopnia naturalności i kierunków przekształceń roślinności w oparciu o metody: fitosocjologiczną i krajobrazową (na przykładzie wsi Guciów na Roztoczu Środkowym). / Estimation of the naturality degree and transformation directions of the vegetation based on phytosociological and landscape methods (an example from the village of Guciów - Central Roztocze). Regionalne Studia Ekologiczno-Krajobrazowe. Problemy Ekologii Krajobrazu, 15, Polska Asocjacja Ekologii Krajobrazu, Warszawa, part I: 401-412.

Hi ck s S., Hyvärinen V. P., 1986. Sampling modern pollen deposition by means of 'Tauber traps': some considerations. Pollen et Spores, 28: 219-242.

Hicks S., A mmann B., Latałow a M., Pardoe H., Tinsley H., 1996. European Pollen Monitoring Programme. Project Description and Guidelines. Oulu Univ. Press, Oulu, Finland.

Izdebski K., Czarnecka B., Grądziel T., Lorens B., P o pi ołe k Z., 1992. Zbiorowiska roślinne Roztoczańskiego Parku Narodowego na tle warunków siedliskowych. / Plant communities against the background of the Roztocze National Park habitat conditions. Wyd. UMCS, Lublin.

Kasprzyk I., Uruska A., Szczepanek K., Latałowa M., Gawel J., Harmata K., Myszkowska D., Stach A., Stępalska D., 2004. Regional differentiation in the dynamics of the pollen seasons of Alnus, Corylus and Fraxinus in Poland (preliminary results). Aerobiologia, 20: 141-151.

Kas zew ski B. M., 2008. Warunki klimatyczne Lubelszczyzny. / Climate conditions of the Lublin region. Wydawnictwo UMCS (in press).

Krawiarz K, Chałupka W., 1980. Fizjologia wzrostu i rowoju. / Physiology of growth and development. [In:] Białobok S (Ed.). Olsze - Alnus Mill. Nasze drzewa leśne, 8. Wyd. PAN, Warszawa-Poznań 1980: 165-200.

Levetin E., Rogers C. \& Hall S., 2000, Comparison of pollen sampling with a Burkard Spore Trap and Tauber Trap in a warm temperate climate. Grana, 39: 294-302.

Łomnicki A., 1995, Wprowadzenie do statystyki dla przyrodników. / Introduction to statistics for nature scientists. Wydawnictwo Naukowe PWN. Warszawa

Matus zki ew i c z W., 2001. Przewodnik do oznaczania zbiorowisk roślinnych Polski. PWN, Warszawa.

Pidek. I. A. 2004. Preliminary results of pollen trapping in the region of the Roztocze National Park (SE Poland). Annales UMCS, sect. B, vol. LIX, Lublin; 143-159.

P i d e k I. A., 2007. Nine-year record of Alnus pollen deposition in the Roztocze region (SE Poland) with relation to vegetation data, Acta Agrobot. 60, 2: 57-64.
Pidek I. A., Weryszko-Chmielewska E., Piotrowska K. 2008. Czy istnieje dwuletni rytm obfitego pylenia brzozy i olszy? / Does the biannual rhythm of abundant birch and alder flowering exist? Alergologia. Immunologia, 5 (2): 61-65.

Pi otrowska K., 2008. Ecological features of flowers and the amount of pollen released in Corylus avellana (L.) and Alnus glutinosa (L.) Gaertn. Acta Agrobot. 61 (1): 33-39.

Ranta H., Sokol C. \& Hicks S., 2007. Comparison of time-series measurements between a volumetric air sampler and a Tauber pollen trap in the northern treeline area of Fennoscandia. Presentation at the 6th International Meeting of the Pollen Monitoring Programme, 3-9 June 2007, Jurmala, Latvia.

Rodriguez-Rajo F. J., Dopazo A., Jato V., 2004. Environmental factors affecting the start of pollen season and concentrations of airborne pollen in two localities of Galicia (NW Spain). Ann Agric Environ Med, 11: 35-44.

Rodriguez-Rajo F. J., Valencia-Barrera R. M., Vega-Maray A. M., Suarez F.J., FernandezGonzalez D., Jato V., 2006. Prediction of airborne Alnus pollen concentration by using ARIMA models. Ann. Agric. Environ. Med.13: 25-32.

Smith M., Emberlin J., Stach A., Czarnecka-Operacz M., Jenerowicz D., Silny W., 2007. Regional importance of Alnus pollen as an aeroalergen: a comparative study of Alnus pollen counts from Worcester (UK) and Poznań (Poland). Ann. Agric. Environ. Med. 14: 123-128.

S to c k m ar r J. 1971. Tablets with spores used in absolute pollen analysis. Pollen et Spores, 13: 615-621.

Suszka B., 1980. Rozmnażanie generatywne / Generative propagation. [In:] Białobok S. (Ed.). Olsze / Alder (Alnus Mill.). Nasze drzewa leśne, 8. PWN, WarszawaPoznań: 99-144.

Szczepanek K., 2006. Pyłek wybranych taksonów roślin w powietrzu Krakowa, 1993-1997 (metoda grawimetryczna). / Pollen of selected plant taxa in the air of Kraków in 1993-1997 years (gravimetric method). [In:] Weryszko-Chmielewska E. (Ed.) Pyłek roślin w aeroplanktonie różnych regionów Polski, Wyd. Wydz. Farmaceutyczny AM, Lublin: 13-20.

Tauber H., 1974. A statistic non-overload pollen collector. New Phytologist, 73: 359-369.

Weryszko-Chmielewska E. (ed.), 2006. Pyłek roślin w aeroplanktonie różnych regionów Polski. / Pollen in aeroplankton of different regions of Poland. Wyd. Wydz. Farmaceutyczny AM, Lublin.

Weryszko-Chmielewska E., Piotrowska K., 2004. Airborne pollen calendar of Lublin, Poland. Ann. Agric. Environ.Med. 11: 91-97.

Weryszko-Chmielewska E., Piotrowska K., 2006. Pyłek wybranych taksonów roslin w powietrzu Lublina w latach 2001-2005. / Pollen of selected plant taxa in the air of Lublin in 2001-2005 years. [In:] E.WeryszkoChmielewska (Ed.) Pyłek roślin w aeroplanktonie róż- 
nych regionów Polski. / Pollen in aeroplankton of different regions of Poland. Wyd. Wydz. Farmaceutyczny AM, Lublin: 105-115.

Weryszko-Chmielewska E., Rapiejko P., 2007. Analysis of Alnus spp. pollen seasons in Lublin and Warszawa (Poland), 2001-2007. Acta Agrobot. 60 (2): 87-97.

Zając A., Zając M. (eds.) 2001. Atlas rozmieszczenia roślin naczyniowych w Polsce. Pracownia Chorologii Komputerowej Instytutu Botaniki Uniwersytetu Jagiellońskiego, Kraków.

\section{Roczne sumy pyłku Alnus w Lublinie i na Roztoczu w latach 2001-2007 na tle wybranych elementów pogody}

\section{Streszczenie}

Olsza (Alnus Mill.), jako takson wiatropylny, produkuje duże ilości łatwo rozprzestrzeniającego się pyłku. Porównano roczne sumy pyłku zarejestrowane w południowo-wschodniej Polsce - w Lublinie (metoda wolumetryczna - aparat Lanzoniego) oraz w okolicach wsi Guciów w regionie Roztocza Środkowego (opad do pułapek Taubera). Wysokość ustawienia punktu pomiarowego oraz roślinność lokalna i regionalna a także odległość od najbliższych zbiorowisk olszowych różnią się w obydwu przypadkach, podobnie jak różni się klimat tych dwu regionów. Analizowana seria danych pyłkowych obejmuje lata 1998-
2007 na Roztoczu oraz 2001-2007 w Lublinie. Odnotowano duże różnice w wartościach depozycji pyłku Alnus pomiędzy poszczególnymi latami. Wśród nich zaobserwowano lata o bardzo wysokiej sumie rocznej (2001, 2003, 2006), a także lata o niskich wartościach depozycji w obydwu regionach $(2002,2005,2007)$. Średnia wartość rocznej depozycji pyłku Alnus obliczona dla Lublina wynosiła w analizowanym okresie 5372 ziarna pyłku olszy w $\mathrm{m}^{3}$ powietrza, a na Roztoczu 1647 ziarna na $\mathrm{cm}^{2}$ powierzchni gruntu. Podczas siedmiu lat monitoringu odnotowano bardzo podobne tendencje dotyczące koncentracji pyłku olszy w powietrzu w obu punktach pomiarowych. Dane pyłkowe zestawiono z czynnikami meteorologicznymi wpływającymi na produkcję i depozycję pyłku olszy. Były to suma opadów i średnia miesięczna temperatura powietrza $\mathrm{w}$ czerwcu, lipcu i sierpniu w roku poprzedzającym pylenie oraz te same elementy pogody w styczniu i lutym w roku pylenia. Na Roztoczu wykazano istotną statystycznie negatywną korelację sum rocznych pyłku Alnus z sumą opadów w sierpniu $\mathrm{w}$ roku poprzedzającym pylenie olszy i w lutym w roku pylenia. W obydwu regionach, współczynnik korelacji Spearmana nie wykazuje istotnych statystycznie wartości przy porównywaniu sum rocznych pyłku Alnus ze średnią temperaturą miesięczną zarówno stycznia i lutego, jak i miesięcy letnich w roku poprzedzającym pylenie olszy. 